\title{
PERTUMBUHAN RUMPUT LAUT Gracilaria sp. PADA MEDIA BIOREMEDIATOR LIMBAH UDANG VANAME DI BANYUWANGI
}

\author{
Mega Yuniartik ${ }^{\mathrm{a}, *}$, Agustina Tri Kusuma Dewia, Akbar Sandi Wijaya ${ }^{\mathrm{a}}$, Ervina Wahyu Setyaningruma \\ aprogram Studi Ilmu Perikanan, Universitas 17 Agustus 1945 Banyuwangi, \\ Jl. Adi Sucipto No, 26, Banyuwangi \\ *Koresponden penulis : megayuniartik@untag-banyuwangi.ac.id
}

\begin{abstract}
Abstrak
Intensifikasi budidaya udang vaname dilakukan dalam rangka peningkatan produksi budidaya. Penerapan tersebut berdampak pada penurunan kualitas lingkungan karena tingginya limbah yang dihasilkan. Bioremediasi limbah budidaya udang vaname dengan memanfaatkan tumbuhan air dinilai mampu meningkatkan kualitas perairan. Gracilaria sp. merupakan salah satu tumbuhan yang dapat dimanfaatkan untuk proses perbaikan kualitas lingkungan, terutama dalam penyerapan limbah bahan organik. Penelitian ini bertujuan mengetahui pertumbuhan rumput laut dengan media limbah budidaya udang vaname, serta kualitas air selama pemeliharaan. Metode yang digunakan dalam penelitian ini yaitu eksperimental. Lokasi penelitian yaitu di Pantai Sari, Pulau Santen, dan Bulusan. Masing-masing lokasi terdapat 3 kolam bioremediator dengan ukuran 3x1 m, serta ketinggian air 0,8-0,9 m. Penelitian dilakukan selama 14 hari, pada bulan Juli-Agustus 2020. Data parameter pertumbuhan dan kualitas air diujikan dengan analisa Univariate Analysis of Variance, dan dilanjutkan dengan uji Tukey dengan software SPSS versi 20.0 for Windows. Data pertumbuhan mutlak rumput laut di Pantai Sari, Pulau Santen, dan Bulusan masing- masing 1,668 $\pm 1,609 \mathrm{~g} ; 0,733 \pm 0,294 \mathrm{~g}$; dan $0,895 \pm 0,313 \mathrm{~g}$. Laju pertumbuhan harian rumput laut yaitu masing-masing 3,03 $\pm 0,968 \% /$ hari, $1,909 \pm$ $0,71 \%$ /hari, dan 2,286 $\pm 0,76 \%$ /hari. Parameter kualitas air di ketiga lokasi menunjukkan perbaikan yang optimal, terutama di peningkatan oksigen terlarut dan penurunan nilai amonia.
\end{abstract}

Kata kunci: Gracilaria sp., pertumbuhan, bioremediator, limbah budidaya udang

\begin{abstract}
The intensification vaname shrimp culture is carried out in order to increase cultivation production. This application has an impact on environmental quality degradation due to the high waste generated. Bioremediation of vaname shrimp cuture waste by utilizing aquatic plants is considered to be able to improve water quality. Gracilaria sp. is one of the aquatic plants that can be used for the process improving environmental quality, especially in the absorption of organic waste. This study aims to determine the growth of seaweed using vaname shrimp culture waste media, and water quality during bioremediation process. The method used in this research is experimental. The research locations were Pantai Sari, Pulau Santen, and Bulusan. Each location has 3 bioremediation ponds with a size of $3 \times 1 \mathrm{~m}$, and a water level of 0.8-0.9 m. The study was conducted for 14 days, in July-August 2020. Growth parameter data and water quality were tested using Univariate Analysis of Variance, and continued with Tukey's test with SPSS software version 20.0 for Windows. The absolute growth data of seaweed at Pantai Sari, Pulau Santen, and Bulusan were 1.668 \pm 1.609 $\mathrm{g} ; 0.733 \pm 0.294 \mathrm{~g}$; and $0.895 \pm 0.313 \mathrm{~g}$, , respectively. Specific growth rates of seaweed were $3.03 \pm$ $0.968 \% /$ day, $1.909 \pm 0.71 \% /$ day, and $2.286 \pm 0.76 \% /$ day, respectively. Water quality parameters at three locations shows optimlas improvements, especially in increasing dissolved oxygen, and decreasing ammonia.
\end{abstract}

Keywords: Gracilaria sp., growth, bioremediation, shrimp waste aquaculture

\section{PENDAHULUAN}

Intensifikasi kegiatan budidaya dilakukan dalam rangka pemenuhan produksi udang untuk konsumsi masyarakat. Produksi udang di Indonesia mencapai 200.591 ton pada tahun 2019 [1]. Kegiatan budidaya pada umumnya menghasilkan sejumlah limbah [2]. Limbah ini berasal dari sisa metabolisme [2], pakan [2], [3], bahan kimia, dan pathogen [3]. Sejalan dengan peningkatan produksi tersebut, terdapat dampak lain yang ditimbulkan yaitu peningkatan limbah budidaya. Peningkatan limbah budidaya juga berpengaruh kepada 
masalah masyarakat dan keberlanjutan kegiatan budidaya [3]. Data menunjukkan kerusakan lingkungan berdampak pada timbulnya berbagai jenis penyakit yang menyebabkan kegagalan panen dan turunnya produksi udang di beberapa negara, termasuk Indonesia [4]

Beberapa teknologi telah dilakukan untuk menciptakan budidaya yang ramah lingkungan. Salah satu upaya yang dilakukan dalam rangka pengurangan limbah bahan organik dapat dilakukan teknologi bioremediasi. Bioremediasi merupakan suatu teknologi dengan memanfaatkan mikroba atau enzim [2], dan tumbuhan untuk mengurangi atau menghilangkan bahan pencemar di lingkungan [5].

Tanaman rumput laut Gracilaria sp. digunakan sebagai agen bioremediator [5], [6]. Hal ini dikarenakan memiliki kemampuan yang tinggi dalam menyerap nitrogen dan dapat memanfaatkan limbah bahan organik sebagai sumber nutrient untuk energi dan pertumbuhan [5]. Berdasarkan hal tersebut kita dapat memanfaatkan potensi dari Gracilaria sp. dalam mengurangi limbah hasil budidaya udang vaname, selain itu juga bias berpotensi meingkatkan pertumbuhan rumput laut itu sendiri.

Penelitian ini bertujuan untuk mengetahui pertumbuhan rumput laut pada media limbah budidaya udang.

\section{METODE}

\section{Lokasi Penelitian}

Penelitian ini dilakukan di lokasi budidaya udang vaname dengan sistem intensif di Kecamatan Banyuwangi, Jawa Timur pada bulan Juli-Agustus 2020. Lokasi budidaya terdapat di 3 lokasi yaitu daerah Pantai Sari, Pulau Santen, dan Bulusan. Lokasi penelitian dapat dilihat pada Gambar 1.

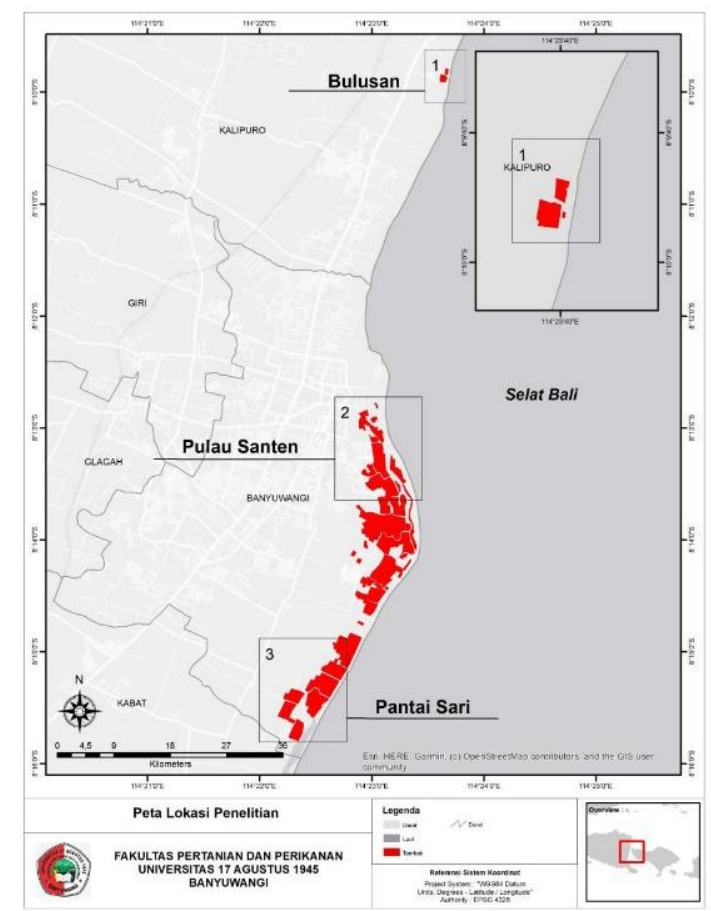

Gambar 1. Peta lokasi penelitian

\section{Desain Penelitian}

Pada 3 lokasi budidaya masing-masing terdapat 3 kolam bioremediasi. Proses bioremediasi dilakukan pada daerah tambak, yaitu dengan menggunakan kolam terpal dengan ukuran $3 \times 1 \mathrm{~m}$, dengan tinggi air $\pm 0,8$ $0,9 \mathrm{~m}$. Metode penanaman yang dilakukan yaitu metode rawai panjang (long line method). Masing-masing kolam tersebut ditanami dengan bibit rumput laut dengan berat awal 5 gram, dengan masing-masing jarak $13-15 \mathrm{~cm}$.

\section{Sampling}

Pertumbuhan rumput laut Gracilaria sp. diamati setiap 7 hari sekali. 10 bagian rumput laut pada kolam bioremediasi diambil dan ditimbang. Biomassa berat basah (gram berat basah) ditimbang dengan menggunakan timbangan digital. Penimbangan dilakukan dengan dilap menggunakan kain/ handuk, hingga bobotnya stabil

\section{Pertumbuhan Mutlak}

Pertumbuhan mutlak dihitung dengan menggunakan rumus [7]: 


$$
\mathrm{G}=\mathrm{W}_{\mathrm{t}}-\mathrm{W}_{0}
$$

Dimana:

$\mathrm{G}=$ pertumbuhan mutlak $(\mathrm{g})$

$\mathrm{W}_{\mathrm{t}}=$ berat pada akhir penelitian $(\mathrm{g})$

$\mathrm{W}_{0}=$ berat pada awal penelitian $(\mathrm{g})$

\section{Laju Pertumbuhan Spesifik}

Menurut laju pertumbuhan spesifik dihitung dengan menggunakan rumus [6]:

$$
\mathrm{SGR}=\frac{\ln \mathrm{W}_{\mathrm{t}^{-}} \ln \mathrm{W}_{\mathrm{t}-\mathrm{n}}}{\mathrm{n}} \times 100
$$

Dimana laju pertumbuhan spesifik (SGR) diketahui \%/ hari. Wt adalah berat basah pada hari ke $\mathrm{t}, \mathrm{Wt}-\mathrm{n}$ adalah berat basah pada saat $\mathrm{n}$ hari sebelum $\mathrm{t}$, dan $\mathrm{n}$ adalah selang hari waktu pengambilan sampel.

\section{Parameter Kualitas Air}

Pengukuran parameter kualitas air dalam penelitian ini dapat dilihat pada Tabel 1 . berikut ini.

Tabel 1. Pengukuran kualitas air dan metode

\begin{tabular}{|c|c|c|c|c|}
\hline No. & $\begin{array}{c}\text { Parameter } \\
\text { Kualitas } \\
\text { Air }\end{array}$ & Satuan & $\begin{array}{c}\text { Alat/ } \\
\text { Metode }\end{array}$ & Keterangan \\
\hline 1. & Suhu & ${ }^{\circ} \mathrm{C}$ & Termometer & Setiap hari \\
\hline 2. & $\mathrm{pH}$ & unit & pH paper & Setiap hari \\
\hline 3. & Salinitas & $\mathrm{ppt}$ & $\begin{array}{l}\text { Refrakto- } \\
\text { meter }\end{array}$ & Setiap hari \\
\hline 4. & $\begin{array}{l}\text { Oksigen } \\
\text { terlarut }\end{array}$ & $\mathrm{mg} / \mathrm{L}$ & DO meter & Setiap hari \\
\hline 5. & $\begin{array}{l}\text { Amonia } \\
(\mathrm{NH} 4-\mathrm{N})\end{array}$ & $\mathrm{mg} / \mathrm{L}$ & $\begin{array}{l}\text { Spektrofoto- } \\
\text { meter }\end{array}$ & $\begin{array}{l}\text { Hari ke-0, } \\
\text { ke-7, dan ke- } \\
14\end{array}$ \\
\hline 6. & $\begin{array}{l}\text { Nitrit (NO2- } \\
\mathrm{N})\end{array}$ & $\mathrm{mg} / \mathrm{L}$ & $\begin{array}{l}\text { Spektrofoto- } \\
\text { meter }\end{array}$ & $\begin{array}{l}\text { Hari ke- } 0 \text {, } \\
\text { ke-7, dan ke- } \\
14\end{array}$ \\
\hline 7. & $\begin{array}{l}\text { Nitrat }\left(\mathrm{NO}_{3}^{-}\right. \\
\mathrm{N})\end{array}$ & $\mathrm{mg} / \mathrm{L}$ & $\begin{array}{l}\text { Spektrofoto- } \\
\text { meter }\end{array}$ & $\begin{array}{l}\text { Hari ke- } 0 \text {, } \\
\text { ke- } 7 \text {, dan ke- } \\
14\end{array}$ \\
\hline 8. & $\begin{array}{l}\text { Phospat } \\
\text { (PO4-) }\end{array}$ & $\mathrm{mg} / \mathrm{L}$ & $\begin{array}{l}\text { Spektrofoto- } \\
\text { meter }\end{array}$ & $\begin{array}{l}\text { Hari ke- } 0 \text {, } \\
\text { ke- } 7 \text {, dan ke- } \\
14\end{array}$ \\
\hline
\end{tabular}
pengukuran selama penelitian

Pengamatan kualitas air harian meliputi suhu, $\mathrm{pH}$, salinitas, dan oksigen terlarut. Data tersebut mudah sekali berubah setiap harinya. Selanjutnya data ammonia, nitrit, nitrat dan phospat diamati setiap seminggu sekali, dikarenakan fluktuasinya dalam jangka waktu tertentu.

\begin{abstract}
Analisis Data
Analisis data dilakukan dengan menggunakan software SPSS (Statistical Package for Social Sciences ) versi 20.0 for Windows. Data yang diperoleh dilakukan uji kenormalan data menggunakan statistik Kolmogorove-Smirnov (K-S) dan homogenitas. Langkah selanjutnya adalah dilakukan uji Univariate Analysis of Variance untuk mengetahui ada tidaknya pengaruh pada masing-masing lokasi perlakuan pemberian bioremediator rumput laut Gracilaria sp. terhadap pertumbuhan rumput laut, dan parameter kualitas air.
\end{abstract}

\section{HASIL DAN PEMBAHASAN}

\section{Pertumbuhan Mutlak}

Pertumbuhan mutlak rumput laut selama proses bioremediasi dapat dilihat pada Tabel 2 berikut ini.

Tabel 2. Pertumbuhan mutlak rumput laut

\begin{tabular}{ll}
\hline $\begin{array}{c}\text { Lokasi kolam } \\
\text { perlakuan }\end{array}$ & $\begin{array}{c}\text { Pertumbuhan mutlak }(\mathbf{g}) \\
(\overline{\boldsymbol{x}} \pm \boldsymbol{S D})\end{array}$ \\
\hline Pantai Sari & $1,668 \pm 1,609^{\mathrm{a}}$ \\
Pulau Santen & $0,733 \pm 0,294^{\mathrm{a}}$ \\
Bulusan & $0,8953 \pm 0,313^{\mathrm{a}}$ \\
\hline
\end{tabular}

*huruf yang sama menunjukkan tidak terdapat pengaruh nyata antar perlakuan (Uji T dengan Sig. > 0,05).

Berdasarkan Tabel 2. tersebut dapat kita ketahui bahwa rerata nilai dan analisis statistik pertumbuhan mutlak (g) Gracilaria sp. diketahui tidak terdapat perbedaan yang nyata (Sig.>0,05) antar lokasi penelitian. Nilai pertumbuhan mutlak tertinggi pada kolam bioremediasi di lokasi Pantai Sari yaitu mencapai nilai 1,668 g, kemudian terendah di lokasi Pulau Santen yaitu sebesar 0,733 g. Apabila dilakukan perbandingan antara pertumbuhan mutlak di Pantai Sari dan Pulau Santen, terdapat perbedaan $43,94 \%$. Nilai pertumbuhan mutlak salah satunya dipengaruhi oleh nilai $\mathrm{N}: \mathrm{P}$ rasio. $\mathrm{N}: \mathrm{P}$ rasio merupakan perbandingan antara total $\mathrm{N}$ (amonia, nitrit, dan nitrat) dengan nilai phosfat. Nilai N:P rasio pada penelitian ini yaitu $0,42 \mathrm{di}$ 
lokasi Pantai Sari, 1,30 di Pulau Santen, dan 1,34 di Bulusan. Penelitian yang dilakukan oleh [8] pertumbuhan mutlak dengan sistem pemeliharaan dengan rasio $\mathrm{N}: \mathrm{P}$ berbeda dengan masa pemeliharaan 2 minggu yaitu pada 6:1 pertumbuhan mutlak mencapai $1,91 \mathrm{~g}$, $\mathrm{N}: \mathrm{P}=6: 2$ pertumbuhan mencapai. Hal ini menunjukkan bahwa meski nilai $\mathrm{N}: \mathrm{P}$ rasio rendah di Pantai Sari, namun memiliki pertumbuhan mutlak tertinggi. Nilai N:P rasio pada penelitian ini rendah dikarenakan tingginya kandungan phospat yang dimiliki. Hal ini menunjukkan bahwa pertumbuhan rumput laut dipengaruhi oleh phospat. Pengkayaan unsur $\mathrm{P}$ pada pemeliharaan rumput laut Gracilaria tikvahiae meningkatkan pertumbuhan rumput laut tersebut. Unsur $\mathrm{P}$ sebagai faktor pembatas dalam produktifitas makrolga dalam studi kasus di Florida Keys [9]. Perbedaan nilai N:P rasio yang terjadi disebabkan perbedaan sistem budidaya yang dilakukan. Sistem budidaya di Pantai Sari dilakukan dengan sistem resirkulasi, sedangkan pada lokasi Pulau Santen dan Bulusan menggunakan sistem semi-tertutup. Perbedaan sistem tersebut tidak memberikan pengaruh yang signifikan terhadap pertumbuhan mutlak rumput laut. Kualitas air tambak dengan menggunakan pola resirkulasi sistem tandon dan pergantian air 12 kali pada saat periode pasang dan pengurang air, tidak berpengaruh pada konsentrasi bahan organik terlarut yang dihasilkan [10].

\section{Laju Pertumbuhan Spesifik}

Pertumbuhan rumput laut Gracilaria sp. pada media air limbah budidaya udang vaname. Data laju pertumbuhan spesifik rumput laut dapat dilihat pada Tabel 3. berikut ini

Tabel 3. Laju pertumbuhan spesifik rumput laut

\begin{tabular}{|c|c|c|}
\hline \multirow{2}{*}{$\begin{array}{c}\text { Lokasi } \\
\text { kolam } \\
\text { perlakuan }\end{array}$} & \multicolumn{2}{|c|}{$\begin{array}{c}\text { Laju pertumbuhan spesifik } \\
(\% / h a r i)(\bar{x} \pm S D)\end{array}$} \\
\hline & I & II \\
\hline Pantai Sari & $3,03 \pm 0,968$ & $3,19 \pm 2,961^{a}$ \\
\hline Pulau & $0,237 \pm 0,112$ & $1,909 \pm 0,71^{\mathrm{a}}$ \\
\hline Santen & & \\
\hline Bulusan & $0,370 \pm 0,085$ & $2,286 \pm 0,76^{a}$ \\
\hline
\end{tabular}

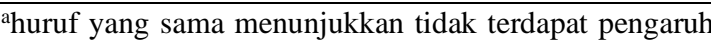
nyata antar perlakuan (Uji T dengan Sig. > 0,05).
Berdasarkan Tabel 3. tersebut dapat kita ketahui bahwa rerata nilai dan analisis statistik laju pertumbuhan harian (\%/hari) Gracilaria sp. diketahui tidak terdapat perbedaan yang nyata (Sig.>0,05). Nilai laju pertumbuhan harian tertinggi pada kolam bioremediasi di lokasi Pantai Sari yaitu mencapai nilai 3,19\%/hari, kemudian terendah di lokasi Pulau Santen yaitu sebesar 1,909\%/hari. Sejalan dengan penelitian [5], bahwa nilai laju pertumbuhan harian rumput laut yang ditanam dalam media limbah berkisar antara 1,8 $8,8 \%$ /hari. Apabila dilihat dari data di atas terdapat peningkatan laju pertumbuhan dari sampling ke-1 dan ke-2. Kenaikan laju pertumbuhan rumput laut menunjukkan adanya perpanjangan sel rumput laut, sehingga berpengaruh terhadap bobot rumput laut. Pertumbuhan rumput laut terjadi karena limbah budidaya udang vaname mampu menyediakan unsur hara untuk proses pertumbuhannya. Limbah budidaya udang vaname dari ketiga lokasi memiliki nilai amonia dan phospat yang cukup tinggi. Penelitian [11] kandungan bahan organik pada limbah budidaya udang vaname sangat tinggi. Limbah tersebut berasal dari sisa pakan ataupun hasil metabolisme. Selain itu, Gracilaria sp, mampu untuk menyerap 6,5\% nitrogen yang terlarut dalam air, dan memanfaatkannya untuk pertumbuhan [12].

\section{Parameter kualitas air}

Data parameter kualitas air selama proses bioremediasi dapat dilihat pada Tabel 4 . Oksigen terlarut pada ketiga lokasi menunjukkan terdapat perbedaan nyata. Oksigen terlarut berkisar 0,4-6,8 mg/L. Nilai oksigen terlarut yang rendah di lokasi Pulau Santen dan Bulusan disebabkan kandungan amonia yang tinggi. Nilai amonia yang tinggi menyebabkan kebutuhan oksigen tinggi dalam proses nitrifikasi. Penelitian [14] menyebutkan oksigen terlarut yang optimum 6-7 mg/L.

Suhu pemeliharaan berkisar 24,26-27,05 ${ }^{\circ} \mathrm{C}$. Berdasarkan penelitian [8], nilai suhu yang optimal untuk pertumbuhan rumput laut berkisar 23-28 ${ }^{\circ} \mathrm{C}$. Hal ini menunjukkan kisaran suhu yang terukur masih dalam kategori yang optimal untuk rumput laut.

Salinitas selama pemeliharaan berkisar antara 16-17 ppt. Rumput laut Gracilaria sp. mampu hidup dengan kisaran salinitas yang 
luas. Meskipun dengan kisaran tersebut, rumput laut masih bisa tumbuh.Penelitian [14] menyebutkan bahwa salinitas yang optimum untuk pertumbuhan Gracilaria sp. antara 15$30 \mathrm{ppt}$.

Tabel 4. Data pengamatan parameter kualitas air limbah budidaya udang di Banyuwangi setelah pemberian bioremediator

\begin{tabular}{|c|c|c|c|c|}
\hline $\begin{array}{l}\text { Parameter } \\
\text { kualitas } \\
\text { air }\end{array}$ & $\begin{array}{c}\text { Pantai } \\
\text { Sari } \\
(\bar{x} \pm \\
S D)\end{array}$ & $\begin{array}{c}\text { Pulau } \\
\text { Santen } \\
(\bar{x} \pm \\
S D)\end{array}$ & $\begin{array}{c}\text { Bulusan } \\
(\bar{x} \pm \\
S D)\end{array}$ & $\begin{array}{c}\text { Baku Mutu } \\
\text { Efluen } \\
\text { Tambak } \\
{[13]}\end{array}$ \\
\hline $\begin{array}{l}\text { Oksigen } \\
\text { terlarut } \\
(\mathrm{mg} / \mathrm{L})\end{array}$ & $\begin{array}{c}6,18 \pm \\
0,23^{\mathrm{c}}\end{array}$ & $\begin{array}{l}1,08 \underset{ \pm}{ \pm} \\
0,175^{b}\end{array}$ & $\begin{array}{l}0,4117 \pm \\
0,21^{\text {a }}\end{array}$ & $<3$ \\
\hline Suhu $\left({ }^{\circ} \mathrm{C}\right)$ & $\begin{array}{c}27,05 \pm \\
0,61^{\mathrm{a}}\end{array}$ & $\begin{array}{l}26,6 \pm \\
1,56^{\mathrm{a}}\end{array}$ & $\begin{array}{c}24,26 \\
0,404^{\mathrm{a}}\end{array}$ & - \\
\hline $\begin{array}{l}\text { Salinitas } \\
\text { (ppt) }\end{array}$ & ${ }_{0,76^{\mathrm{a}}}^{ \pm}$ & $\begin{array}{l}16 \pm \\
0,5^{\text {a }}\end{array}$ & $\begin{array}{cc}17 & \pm \\
0,28^{\mathrm{a}} & \end{array}$ & - \\
\hline $\mathrm{pH}$ & $\begin{array}{c}8,23 \pm \\
0,19^{\mathrm{c}}\end{array}$ & $\begin{array}{l}5,07 \pm \\
0,163^{\mathrm{b}}\end{array}$ & $\int_{0,176^{\mathrm{a}}}^{7,1} \pm$ & $6-9$ \\
\hline $\begin{array}{l}\text { Amonia } \\
\left(\mathrm{NH}_{4}\right) \mathrm{mg} / \mathrm{L}\end{array}$ & $\underset{0,48}{2,13} \pm$ & $\begin{array}{l}15,166 \\
\pm 0,29 \\
\text { b }\end{array}$ & $\begin{array}{l}14,703 \pm \\
0,609^{\mathrm{b}}\end{array}$ & $<0,1$ \\
\hline $\begin{array}{l}\text { Nitrit }\left(\mathrm{NO}_{2}{ }^{-}\right. \\
\mathrm{N}) \mathrm{mg} / \mathrm{L}\end{array}$ & $\begin{array}{l}0,097 \pm \\
0,144 \\
\text { a }\end{array}$ & $\begin{array}{l}0,016 \\
\pm \\
0,004^{\text {a }}\end{array}$ & $\begin{array}{c}0,026 \\
0,007^{\text {a }}\end{array}$ & $<2,5$ \\
\hline $\begin{array}{l}\text { Nitrat }\left(\mathrm{NO}_{4}{ }^{-}\right. \\
\mathrm{N}) \mathrm{mg} / \mathrm{L}\end{array}$ & $\begin{array}{c}0,044 \pm \\
\substack{\mathrm{a} \\
0,074}\end{array}$ & $\begin{array}{l}0,004 \pm \\
0,003^{a}\end{array}$ & $\underset{0,002^{\text {a }}}{0,020} \pm$ & $<75$ \\
\hline $\begin{array}{l}\text { Phospat } \\
\text { (PO4-) } \\
\text { mg/L }\end{array}$ & $\begin{array}{c}5,277 \pm \\
0,697 \\
\text { a }\end{array}$ & $\begin{array}{l}11,97 \\
\pm \\
0,640^{\mathrm{b}}\end{array}$ & $\begin{array}{c}10,974 \pm \\
0,538^{\mathrm{b}}\end{array}$ & $<0,1$ \\
\hline
\end{tabular}

pH selama pemeliharaan berkisar antar 58. $\mathrm{pH}$ juga menjadi salah satu faktor yang berpengaruh terhadap pertumbuhan. Nilai ph yang mendekati netral (7), cenderung memiliki pertumbuhan yang lebih tinggi. Penelitian [14] menyebutkan bahwa, nilai optimum untuk pertumbuhan rumput laut berkisar antara 6-9.

Pengukuran amonia (NH4-N) yang dilakukan, diketahui terdapat perbedaan nyata antara masing-masing lokasi penelitian (Sig.<0,05). Nilai amonia di Pantai Sari menunjukkan nilai terendah yaitu $2,13 \mathrm{mg} / \mathrm{L}$. Nilai ini berbeda nyata dibandingkan nilai amonia di Pulau Santen dan Bulusan, masingmasing $15,166 \mathrm{mg} / \mathrm{L}$ dan $14,703 \mathrm{mg} / \mathrm{L}$. Nilai tersebut masih di atas ambang batas baku mutu effluen tambak udang yaitu $<0,1 \mathrm{mg} / \mathrm{l}$ [13]. Perbedaan nilai amonia yang terjadi disebabkan karena adanya perbedaan sistem budidaya pada ketiga lokasi tersebut. Sistem budidaya di Pantai Sari menggunakan sistem resirkulasi dan semi tertutup, sedangkan di lokasi Bulusan dan Pulau Santen menggunakan sistem semi tertutup. Selain itu pada saat pengambilan limbah ada kemungkinan lumpur ada yang ikut masuk ke dalam kolam bioremediator.

Parameter nitrit, nitrat menunjukkan nilai lebih rendah dibandingkan ambang batas baku mutu, yaitu dibawah $2,5 \mathrm{mg} / \mathrm{L}$ untuk nitrit dan di bawah $75 \mathrm{mg} / \mathrm{L}$ untuk nitrat.

Fosfat berkisar antara 5,277- 11,97 mg/L, nilai ini melebihi ambang batas limbah budidaya udang vaname. Nilai ambang batas fosfat adalah $<0,1 \mathrm{mg} / \mathrm{L}$ [13]. Tingginya nilai fosfat di kolam lokai Pulau Santen dan Bulusan diduga adanya masukan sedimen dalam kolam bioremediator. Penelitian [15] menyebutkan bahwa fosfat yang mengendap dalam bentuk sedimen menyebabkan meningkatkan konsentrasinya dalam limbah yang terbuang.

\section{KESIMPULAN}

Berdasarkan hasil penelitian diketahui rumput laut dapat tumbuh dalam media limbah budidaya udang vaname. Pertumbuhan mutlak dan laju pertumbuhan spesifik tidak memiliki perbedaan yang signifkan pada ketiga lokasi penelitian yang berbeda. Pertumbuhan mutlak dan laju pertumbuhan spesifik tertinggi terdapat pada kolam bioremediator di Pantai Sari yaitu masing-masing $1,668 \mathrm{~g}$ dan $3,14 \%$ /hari.

\section{UCAPAN TERIMA KASIH}

Penelitian ini didukung oleh Kementerian Riset dan Teknologi Republik Indonesia, melalui pendanaan skema penelitian dosen pemula.

\section{DAFTAR PUSTAKA}

[1] S. T. I. P. STIP, "Shrimp Tails," pp. 176, Apr. 2020.

[2] S. P. Antony and R. Philip, "Bioremediation in Shrimp Culture Systems," vol. 29, no. 3, pp. 62-66, 2006.

[3] A. B. Dauda, A. Ajadi, A. S. TolaFabunmi, and A. O. Akinwole, "Waste production in aquaculture: Sources, components and managements in 
different culture systems," Aquac. Fish., vol. 4, no. 3, pp. 81-88, 2019, doi: 10.1016/j.aaf.2018.10.002.

[4] A. S. Harsono, S. Rahardjo, D. Djokosetiyanto, and A. Alamsyah, "Seaweed Utilization for Phytoremediation of Litopenaueus vannamei Shrimp Farming Waste in Recirculation Systems (Environmentally Friendly Design of Sustainable Shrimp Culture)," Sustain. Futur. Hum. Secur., vol., no., pp. 145-158, 2018.

[5] W. Komarawidjaja, "Rumput Laut Gracilaria sp. sebagai Fitoremedian Bahan Organik Perairan Tambak Budidaya," Tek. Lingkung. P3TL-BPPT, vol. 6, no. 2, pp. 410-415, 2005.

[6] Y. Huo et al., "Bioremediation efficiency of Gracilaria verrucosa for an integrated multi-trophic aquaculture system with Pseudosciaena crocea in Xiangshan harbor, China," Aquaculture, vol. 326-329, pp. 99-105, 2012, doi: 10.1016/j.aquaculture.2011.11.002.

[7] Y. N. Ihsan, A. Aprodita, I. Rustikawati, and T. D. K. Pribadi, "Kemampuan Gracilaria sp. sebagaia agen bioremediasi dalam menyerap logam berat Pb," J. Kelaut., vol. 8, no. 1, pp. 10-18, 2015.

[8] V. A. Cyntya, G. W. Santosa, E. Supriyantini, and S. Y. Wulandari, "Pertumbuhan Rumput Laut Gracilaria sp. Dengan Rasio N:P Yang Berbeda," $J$. Trop. Mar. Sci., vol. 1, no. 1, pp. 15-22, 2018, doi: 10.33019/jour.trop.mar.sci.v1i1.655.
[9] B. E. Lapointe, "Phosphorus- and nitrogen-limited photosynthesis and growth of Gracilaria tikvahiae (Rhodophyceae) in the Florida Keys: an experimental field study," Mar. Biol., vol. 93, no., pp. 561-568, 1987.

[10] Gunarto, Muslimin, and A. Mansyur, "Budi Daya Udang Windu Pada Tambak Pola Resirkulasi Menggunakan Sistem Tandon," J. Penelit. Perikan. Indones., vol. 10, no. 5, pp. 91-102, 2004.

[11] P. Chávez-Crooker and J. ObrequeContreras, "Bioremediation of aquaculture wastes," Curr. Opin. Biotechnol., vol. 21, no. 3, pp. 313-317, 2010, doi: 10.1016/j.copbio.2010.04.001.

[12] M. Troell, P. Rönnbäck, C. Halling, N. Kautsky, and A. Buschmann, "Ecological engineering in aquaculture: Use of seaweeds for removing nutrients from intensive mariculture," J. Appl. Phycol., vol. 11, no. 1, pp. 89-97, 1999, doi: 10.1023/A:1008070400208.

[13] KKP, Pedoman Umum Budidaya Udang di Tambak. 2004.

[14] I. M. Widiastuti, "Produksi Gracilaria verrucosa Yang Dibudidayakan Di Tambak Dengan Berat Bibit Dan Jarak Tanam Yang Berbeda," J. Agrisains, vol. 12, no. 1, pp. 57-62, 2011.

[15] M. Fahrur and M. C. Undu, "Karakteristik air buangan limbah budidaya udang vaname superintensif," Prosiding, no. 2002, pp. 1015-1026, 2015. 